\title{
Political Economy Analysis of the Macroeconomic Impact of National Elections in Ghana During the Fourth Republican Era, 1992 to 2016
}

\author{
Kwabena Asomanin Anaman ${ }^{1} \&$ Gbensuglo Alidu Bukari ${ }^{2}$ \\ ${ }^{1}$ Professor, Department of Agricultural Economics and Agribusiness, College of Basic and Applied Sciences, \\ University of Ghana, Legon, Accra, Ghana \\ ${ }^{2}$ C/o Kandia Basic School, Post Office Box 99, Gwollu, Upper West Region, Ghana \\ Correspondence: Kwabena Asomanin Anaman, Department of Agricultural Economics and Agribusiness, College of \\ Basic and Applied Sciences, University of Ghana, Legon, Accra, Ghana.
}

\author{
Received: January 25, $2019 \quad$ Accepted: February 11, $2019 \quad$ Available online: April 8, 2019 \\ doi:10.11114/aef.v6i3.4202 URL: https://doi.org/10.11114/aef.v6i3.4202
}

\begin{abstract}
The study dealt with the analysis of macroeconomic impact of national presidential elections in Ghana during the Fourth Republican period from 1992 to 2016 based on effects of these elections on economic growth, government budget deficits, inflation and interest rates. Using annual data covering the period, 1992 to 2016, the analysis indicated that national elections did not lead to significant increase in annual economic growth as measured by the changes in real gross domestic product (GDP). However, the increase in government budget deficits during election years was established. Further, based on quarterly data covering 100 periods from 1992 to 2016, we showed that elections produced significantly higher levels of inflation and interest rates. Our study confirmed anecdotal evidence of worsening macroeconomic performance of the economy of Ghana as a result of national presidential elections which hurt ordinary Ghanaians especially those living on fixed incomes such as pensioners due to higher inflation, and also adversely affected small and medium scale businessmen as a result of increased borrowing costs from higher interest rates.
\end{abstract}

Keywords: Africa, democracy, Ghana, macroeconomics, political business cycles, political economy of elections

\section{Introduction and Problem Statement}

Ghana is an English-speaking nation in West Africa with a land mass of 238,535 square kilometres and a population of about 30 million (March 2019 estimate), growing at an annual rate of $2.5 \%$, based on projections from the 2010 Population and Housing Census data (Ghana Statistical Service, 2013). Ghana gained its political independence from Great Britain on 6 March 1957 with the independence movement led by Dr. Kwame Nkrumah and the Convention People's Party (CPP). CPP won all three pre-independence national elections held by the Colonial Government in 1951, 1954 and 1956 (Buah, 1998; Davidson, 1972).

After a nine-year of post-independence period stability based on moderate economic growth, Ghana witnessed the first of several military coups on 24 February 1966. This first coup was partly due to a balance of payments crisis in 1965 resulting from historically-low world market prices for its leading export, cocoa, for which the country was then the largest world producer and accounted for 37.5\% of world's production (refer to International Cocoa Organization for world cocoa prices from 1960 to 2019, and Fernandez et al., 2017 for real world commodity prices from 1960 to 2015). The lowest average monthly world cocoa prices were recorded in July 1965 averaging 211 dollars per tonne with the highest monthly price being 4,361.58 dollars per tonne recorded in July 1977. External political pressures from 1963 to 1966 (Hersh, 1978) also contributed considerably to the first military coup. Another factor was the El Nino weather phenomenon. Anaman et al. (2017) suggest that severe El Nino weather events have preceded changes in governments in Ghana, either by military coups or national elections since independence in 1957.

Political instability characterised by five successful military coups and many unsuccessful ones occurred during the 27-year period from the occurrence of the first military coup on 24 February 1966 till 7 January 1993 when the Fourth Constitutional System was promulgated (Anaman, 2006a). After 27 years of political instability from February 1966 to January 1993, the country has remained largely politically stable over the last 26 years with the absence of military coups. However, this 26-year period has been characterized by intermittent localised conflicts around the country often 
related to local cultural and land issues, and occasional violent incidents linked to para-military or "vigilante" groups belonging to the two major political parties, especially during periods close to national and district elections, and also often during periods of bye-elections.

At the national level, since January 1993, the political system has degenerated into a two-party-zero-sum game, or two-party-low-positive sum game, with permanent electioneering campaign and intense struggle for political power in presidential elections that are held once every four years on 7 December. Currently the two main parties are the ruling New Patriotic Party (NPP) and the National Democratic Congress (NDC). Both parties share similar political ideologies, more akin to the centre-right to the centre of the international ideological continuum. NPP and NDC received around 97\% of the total valid votes cast during the last three presidential elections in 2008, 2012 and 2016; although their combined shares of the total votes cast were lower in the four previous elections held in 1992, 1996, 2000 and 2004. With little difference between the two parties in ideologies, mobilization on ethnic and regional differences has become an important tool in electoral campaigns for power.

The incumbent political party spends excessively during years of national elections with the aim of retaining political power (Anaman, 2016; Bukari, 2017). The excessive desire to maintain power exhibited by the incumbent party is due to the large rewards and spoils of electoral victory linked to the extensive political patronage system revolving around the Executive President of the Republic. The extensive political patronage system is similar to the exclusionary practice of appointments and rewards in Ghana known in the local Akan language parlance as the "kokofu ball play" or the "kokofu political economy game".

The Executive President of the Republic has considerable powers including the appointment of National Sector Ministers, Ministers and Deputy Ministers of the 16 regions (currently totalling 123 Ministers), all Chief Executives and Mayors of the 260 administrative districts, thousands of State appointees, and administration of a government budget of about 15 billion United States dollars (US\$) each year, or US\$60 billon over a four-year presidential term. Many other appointments characterized by exclusionary perks and privileges need to be approved by the President. These include major international appointments, members of Boards of numerous state-owned corporations and entities and quasi-government agencies, access to foreign scholarships, and management of hundreds of billions of State-owned investments, foreign exchange reserves and natural and environmental assets and resources, and many State-sponsored contracts and civil works linked to the annual government budget.

The fierce nature and permanent national electioneering campaign in Ghana, dominated by the NPP and NDC, reflects the intense competitive struggle by the political class elites for power, due to the winner-takes-all and the loser-goes-home-with-nothing political system. The political class elites of the two main parties (NPP and NDC) are largely dominated by academics, businessmen, lawyers and other professionals from eight relatively big social/ethnic groups out of the 88 social/ethnic groups in the country identified by Ghana Statistical Service (2013) and the Bureau of Ghanaian Languages. ${ }^{1}$

The rewards and spoils of the extensive political patronage system accrue disproportionately to the political class elites of two or three of the eight relatively big social/ethnic groups that are closely tied to the winning party (either NPP or NDC) in a national presidential election. Numerous calls and opinions are expressed in the mass media and social media outlets within the first two years after a national presidential election in Ghana for some form of inclusive government or government of national unity. These calls die down during the third and fourth years of the tenure of the incumbent government as the two main parties prepare intensively to win political power in the next presidential election.

Excessive government spending and related abuse of incumbency including the use of State institutions for partisan political campaigning are the norm in election years in Ghana. This is evidenced by the very high spending observed for

${ }^{1}$ Based on data from national population censuses organized by the Ghana Statistical Service in 1960, 1970, 1984, 2000 and 2010, there are about 88 language groups and dialects in Ghana (social/ethnic groups). Using the more reliable ethnic classification figures from the 2000 population census, the major social/ethnic groups based on population strength are (1) Asantes (14.8\%), (2) Ewes (12.7\%), (3) Fantes (9.9\%), (4) Akyems/Akuapems (6.4\%), (5) Bonos (4.6\%), (6) Dangmes (4.3\%), (7) Dagombas (4.3\%), and (8) Gas (3.4\%). The Akyems and Akuapems are identical social/ethnic groups based on the migration of the neighbouring Akyem-Kyebi Asona Royal Family members to the present day Akuapem areas during the $18^{\text {th }}$ Century $\mathrm{AD}$ to establish several key towns such as Akropong and Amanorkrom. These eight major social/ethnic groups constitute about $60 \%$ of the population of Ghana. The remaining 80 social/ethnic groups constitute about $40 \%$ of the population with an average share of the population of about $0.5 \%$, ranging from $0.1 \%$ to $2.2 \%$. 
all incumbent governments in elections during the Fourth Republican era in Ghana, except in 2004. That year, 2004, was the year the government was under a strict supervisory regime by Western development partners as part of the steps that the country agreed to take to directly benefit from the cancellation of two thirds of its total foreign debts. This cancellation of foreign debts occurred in December 2006 and saw the total foreign debts level of the country reduced from US $\$ 6.3$ billion to US $\$ 2.1$ billion. The freeing of fiscal space from January 2007 and the exit from an International Monetary Fund (IMF) support programme led to higher level of borrowing by the government. By the end of December 2008 , the level of foreign debts had doubled to around US\$4 billion. Further, by the end of May 2018, the total foreign debts of Ghana had more than quadrupled to US\$18.5 billion (Government of Ghana, 2018, page 22).

Despite the large scale foreign debts cancellation in December 2006, the infusion of about US\$6.44 billion worth of grants into the economy from overseas development partners over the nine-year period from 2004 to 2012, the start of modest commercial export of crude oil starting in mid-December 2010, and the continuous positive economic growth from 1984 to the present date, Ghana has continued to suffer adverse macroeconomic instability and severe socio-economic problems. The macroeconomic instability included large depreciation of the country's currency, the Ghana cedi, continuously weak balance of trade and balance of payments positions, and the rapid accumulation of domestic and foreign debts since 2007.

Recent economic growth (2017 and 2018), while moderately high, has largely been the result of the investments in the oil industry undertaken by the previous government with foreign oil companies over the 2011 to 2016 period, whose returns started to come on stream in relatively large quantities starting in 2017. The oil industry accounts for only about 5.6\% of GDP and employs a few people (Ghana Statistical Service, 2018a). These 2011 to 2016 investments in the oil industry included the completion of the Atuabo Gas Processing Plant, and the development of major offshore fields by the Government of Ghana with several foreign oil companies such as Tullow, Kosmos Energy, and ENI of Italy.

Since 2013, the three rigid expenditures of the Government of Ghana, related to (1) wages and salaries, (2) debt service expenditures, (3) statutory payments had exceeded its total revenue and grants, (Government of Ghana, 2018, page 23; Boakye, 2017, page 28, Boakye, 2018). As noted by Boakye (2018), in 2017 alone, the three rigid expenditures were 46.35 billion Ghana cedis (GHS); they exceeded total revenue and grants of GHS41.50 billion by GHS4.85 billion, equivalent to about one billion United States dollars ${ }^{2}$. Much of the recent government borrowings are largely used for consumption activities. For example, in 2017, government total capital expenditures as a proportion of GDP was only $3.1 \%$, the lowest in 25 years (refer to Figure 1 for more details), with only about one-sixth (0.5\% of GDP) of the capital expenditures financed through domestic government sources, the remaining five-sixths (2.6\% of GDP) in 2017 were financed with foreign grants and loans.

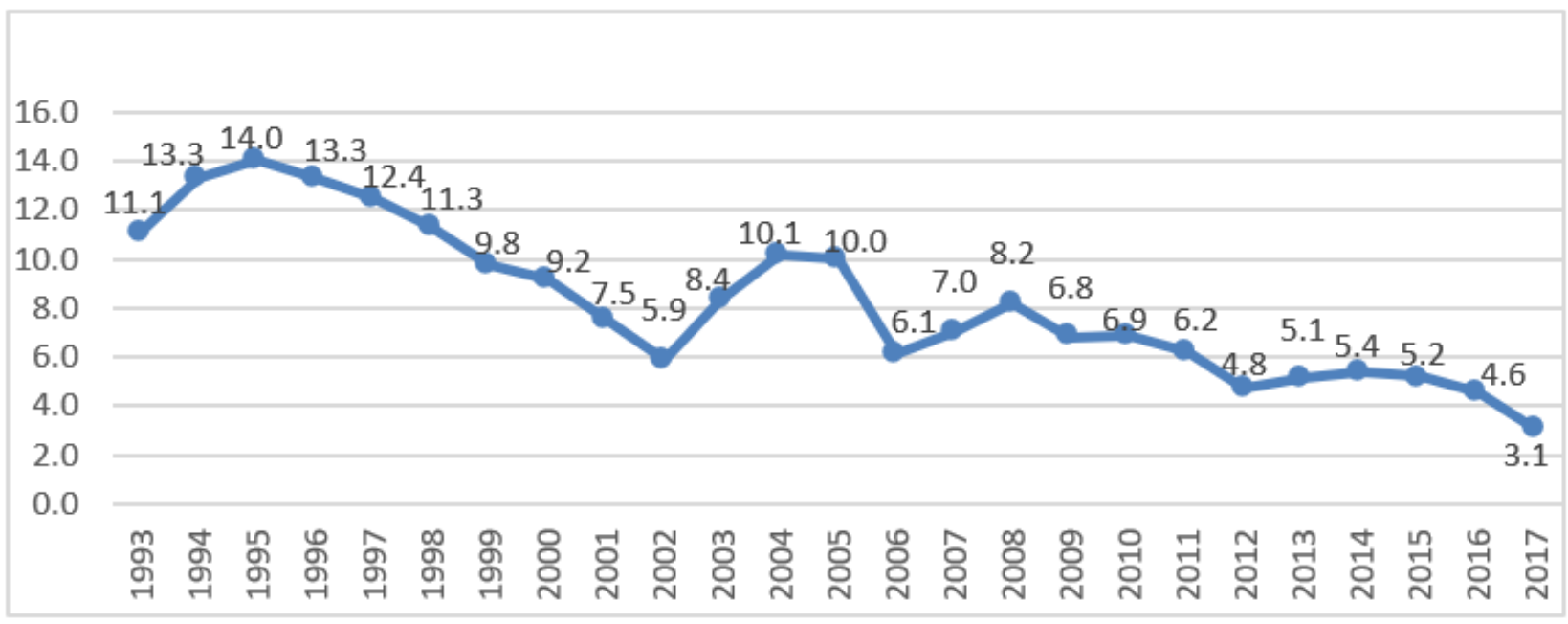

Figure 1. Government capital expenditures as a proportion of GDP, 1993 to 2017

Source: Institute of Fiscal Studies, Accra, Ghana, 2018, page 10.

In addition to election-related excessive spending, the more recent weak macroeconomic position of the country was also caused partly by the end of the decade-long international commodity price boom that occurred during the first decade of the $21^{\text {st }}$ Century, reduced levels of grants and gifts from Ghana's development partners from 2013 onwards, and the severe form of the El Nino weather phenomenon that affected the country in 2007, 2014 and 2015 (Anaman $e t$ al., 2017), which resulted in reduced production from the country's three hydro-electric dams, a major source of

${ }^{2}$ One US dollar was worth about 4.85 Ghana cedis in the inter-bank exchange market as at the end of December 2018. 
electricity energy production in the country.

The excessive spending by the government in 2012, a presidential election year, in a repeat of what occurred in 2008, another election year, led to the refusal of Western development partners to support the government with relatively large amounts of grants and other forms of assistance in 2013 and 2014, as they had done over the 2004 to 2012 period when the country received at least US\$500 million annually. Ghana received annually, an average of US\$715.25 million worth of grants from 2004 to 2012. This average level of annual grants dropped to US\$331.0 million during 2013 and 2014. Appendix 1 provides data about the level of foreign grants received by Ghana from 2000 to 2017. The reduced levels of grants received by the government in 2013 and 2014, coupled with low international commodity prices, and reduced hydro-electricity energy production, resulting from a severe El Nino weather phenomenon, triggered a balance of payments crisis in 2014, characterized by a sharp fall in the value of the local currency, the Ghana cedi. These factors forced the government to enter into an IMF programme in 2015, for which it exited in April 2019.

The socio-economic problems in Ghana include the widening income inequality gap revealed by the last three national living standards surveys completed in 2006, 2013 and 2017 (Ghana Statistical Service (2014, 2018b), currently weak public secondary school educational system (once considered the best in Sub-Saharan Africa from the 1950s to 1970s), very high levels of road traffic accidents and deaths, for example, as reported by the World Health Organization (2017), extensive degradation of forest, lands and water resources through illegal mining and other causes, and the very poor environmental sanitation quality, as documented by various international ranking sources such as World Health Organization/United Nations Children Fund (2017) and Yale University (2018). The widening income inequality was also established by Anaman and Agyei-Sasu (2014) who showed that over the period, 1993 to 2012, the share of GDP accruing to labour had remained virtually constant around 45\%; the share of GDP going to owners of human-made capital such as machinery and equipment increased steadily from 15\% in 2001 to $38 \%$ in 2012.

While the country is sometimes hailed internationally for its three peaceful transitions of power in the Fourth Republican era, in 2001, 2009 and 2017, a major problem that has persisted from the politically-unstable period (1966 to 1992), is the large scale abandonment by a new government of many State-initiated projects and civil works started by the previous government including almost completed facilities and amenities such as public school buildings, clinics, hospitals, market centres and public housing facilities. Similar to the era of military governments, the abandonment of projects started by the previous government, has been recurring as a new government starts its own projects, discrediting the policies and projects of its predecessor. This abandonment of projects leads to the reduced ability of the State to generate revenues to pay for the loans incurred for such projects compounding the problem of debts accumulation for the country which is also exacerbated by large judgment debts paid by the government to local and foreign contractors for abandoned contracts.

Given this background, the main objective of this study is to establish the impacts of national presidential elections on the performance of the macroeconomy in Ghana based on the variables, economic growth, government budget deficits, inflation, and Treasury bond interest rates. The rest of this paper is organized as follows: the next section is the review of the literature on the topic including both theories and empirical works. This is followed by the methodology employed by the study, the results of the econometric analysis, conclusions and some policy recommendations.

This study expands the work of Anaman (2016) by advancing the analysis of impacts of elections in the Fourth Republican era using econometric techniques. It contributes to the international political economy literature by establishing the impacts of national elections in an emerging democracy characterised by a highly-intense competition for political power by political class elites from a few dominant social/ethnic groups. As such this study is relevant to several countries in Africa, Asia and Latin America with such characteristics.

\section{Literature Review}

\subsection{Political Economy Theories of Elections}

Functioning democracies hold regular national elections that allow citizens to choose their leaders to run the affairs of the government and related State institutions for particular periods of time. Political economy theories offer various analytical lenses to analyse and understand national elections and their impacts on various segments of society and the economy as a whole in a more holistic manner. There are several major political economy theories of elections. These include the economically-rational voter theory, game theories, institutionalism theories, new institutional economics theories, and structuralism political economy theories. These theories are briefly discussed below with some emphasis on their relevance in the Ghanaian context.

Downs (1957) is credited for establishing the foundations for the modern political economy theory of elections based on the economically-rational voter theory. Downs assumes that individuals as voters rationally pursue their self interest and that they are concerned with policies that an elected government will implement in terms of benefits that they get. Policies can be represented by single dimension, such as increased government spending on education or increased 
infrastructure for the health sector. The rational voter has preferences for a policy that he/she most prefers, deviations from this policy lead to less satisfaction for that voter. For their part, politicians seek to win office also based on rational self-interest. Political parties are considered as teams of politicians who work together to win power and control the government. Electoral politics deal with policy promises that candidates and parties offer to implement if elected. Voters choose the candidates who champion ideas closest to their ideal set of policies. A common prediction from Downs' model is that electoral competition for office leads to the choice of candidates and/or parties which represent the public policies that most strongly appeal to the median voter. This theory is valid for the $30 \%$ of the voters in Ghana who are swing voters and decide presidential electoral outcomes in the Fourth Republican era (Anaman, 2016; Bukari, 2017).

Game theories, originally developed by von Neumann and Morgenstern (1944), are the second set of theories that are used to analyse outcomes of elections. One variant of game theories, proposed by Dewan and Shepsle (2011), suggests that in an electoral competition, characterised by an electoral rule (proportional, first-past-the-post, and others), and a system of competition (national, local, mixed), the payoffs to political parties and candidates are interdependent; so it is reasonable to assume that they will act strategically, anticipating how other parties and/or candidates will respond to the actions they initially take. In the case of Ghana where there are two main political parties, the kinked demand curve theory proposed by Sweezy (1939) is a suitable framework for analysis. In such a situation, the main opposition party attempts to match a favourable policy announced to electorate by the incumbent party in order to stem the possible loss of votes in swing electoral areas.

Under some game-theoretic situations, a common occurrence is the "Nash equilibrium". This equilibrium is based on two-party, non-cooperative games. Nash equilibrium, as used in the setting of electoral campaigns, can be defined as a set of strategies representing the best self-interested "vote-getting" actions by one political party, given the strategies of the other major political party. Nash equilibrium, developed by Nash $(1950,1951)$, is a common occurrence in Fourth Republican politics in Ghana. The common good of the country, achievable through cooperation, based on actual "Pareto improvement" (Pareto, 1906), and "potential Pareto improvement" (Hicks, 1939; Kaldor, 1939), is often sacrificed under partisan bickering and self-seeking actions of the two main parties, NPP and NDC, in a never-ending electoral campaigning that continues throughout the entire four-year lifespan of an incumbent government.

Institutionalism theories of election acknowledge that elections do not take place in a vacuum but are supervised and managed by State institutions (referees) (Weingast and Wittman, 2006, Chapter 1). Further, electoral competition involves political parties (players) which often act as broad-based churches with ideologies that are fine-tuned by the current party leaders for elections in terms of policies and messages. Political parties therefore provide the vehicles for members of the political class to mobilize support across the country. It is political parties and candidates that structure the choices available to the voting public. Party identification and party labels, as well as the candidate attributes, provide the information for voter choice. Voters have beliefs about what is best for them and/or society, and they act based on the information provided by the political parties and candidates.

Institutionalism theories also acknowledge that electoral institutional structures shape the choices available to voters in an election. In the parliamentary system elections in countries such as the United Kingdom, the electoral choice may involve either the candidates or party lists or some combination of these altogether. In countries where the presidential systems is practiced such as the United States of America, France, Brazil and Ghana, the system provides voters with a level of presidential electoral choice supplementing that of a purely parliamentary or legislative contest. An important electoral structure which influences the turnout and participation in election is whether voting is compulsory or not. For example, voting is compulsory for all citizens in Australia but voluntary in Ghana and Great Britain.

New institutional economics theories extend the approach of economically-rational voter approach of Downs (1957) by explicitly incorporating the institutional rules of elections. Scholars following this tradition challenge theories that assume that voters are generally naïve. They argue that voters in advanced democracies such as the United States are generally aware of deliberate incentives to prop up the economy ahead of election and thus, provide a check (through their vote) on the opportunistic behaviour of incumbents (Rogoff and Sibert, 1988). However, as noted by Dewan and Shepsle (2011), in many situations, time-based asymmetric information exists between politicians and voters. Politicians may pursue actions which are not fully explained to the public before national elections; in the more likely case politicians make promises which they know they cannot fully implement, but are sold to the unsuspecting public in a way that many voters are likely to believe in a bid to win political power.

A view of scholars from the new institutional economics school, which is similar to the view of the institutionalism school of thought, is that for emerging democracies, constitutional arrangements such as amendments to the National Constitution should be seen as part of the rules of the game for seeking political power. New constitutional arrangements are important to develop through enlightened debate when required. Reforms can resolve problems associated with the contentious rules of the political power game, shape the policy agenda and allow more equitable shares of the spoils of the policy processes to accrue to various stakeholders especially those from marginalized groups. 
Structuralism political economy theories indicate that the dominant social/ethnic groups in society largely shape or determine economic and political outcomes in a nation state (Sackrey et al., 2016). With regards to the outcomes of national elections and related control of political power, this dominance of major social/ethnic groups is reflected in at least four major ways. First, with the political class elites contesting for power, using the major political parties as their electoral vehicles, it is the elites from the dominant social/ethnic groups who largely determine or shape electoral outcomes through the setting of agenda and manifestos.

Second, institutions which supervise and manage elections, such as State electoral commissions, are also likely to be led and/or dominated by members of the dominant social/ethnic groups. Third, the drafting of new constitutions and constitutional amendments are also likely to be led by jurists and academics who are members of these dominant groups. Fourth, the presidential candidates of the major political parties tend to persistently come from a few dominant social/ethnic groups. These four factors suggested by structuralism theories are present in Ghana. People from relatively small social/ethnic groups, who account for about $40 \%$ of the population, are under-represented in the area of selected political positions, and also tend to have reduced lengths of tenure when selected for these positions. ${ }^{3}$

\subsection{Democracy and Economic Development}

The linkage between the performance of the economy and the proper functioning of democracy in the nation state has been extensively researched over the last six decades beginning with the seminal work of Lipset $(1959,1960)$. Lipset $(1959,1960)$ suggested a positive relationship between democracy and economic development indicating that as a country becomes wealthier, it is more likely to sustain and enhance democracy and its supporting institutions. This argument by Lipset $(1959,1960)$ suggests that causality runs from economic development to democracy (Harding and Wantchekon, 2010). The reverse causality from democracy to economic development is reported by Olson (1993) arguing that long-term sustainable economic growth and development is only possible through the establishment of democratic institutions. However, Przeworski (2005) has pointed out that the stability and progress of democracy in a country are intertwined with both economic development and minimization of the level of inequality in the nation state.

Causality from economic development to democracy is likely to occur and be sustained when there exists an increasingly growing and large middle class that cuts across the many social/ethnic groups of a country. It is also based on the substantial progress in increasing incomes through economic growth and expanding opportunities and minimising large income inequalities. Further, the quality of democracy means more than just regular holding of national elections and needs to be expanded to include broad participation of the process by citizens. Harding and Wantchekon (2010) argue that democratic institutions lead to increased age-based longevity and knowledge. These two measures of human development are not always linked to human happiness, which is a "bottom line" indicator of human development. Health expectancy is generally preferred to life expectancy as a measure of human happiness. Many people in advanced democracies, living beyond the age of 75, suffer severe loneliness and chronic diseases and are often kept alive by technology.

Increased human knowledge and education have not necessarily led to societies free of conflicts, and improved security free from severe crimes and human degradation. The greatest build up of nuclear weapons and weapons of mass destruction that threaten to destroy the planet take place largely in democratic societies. Further, climate change, an important issue currently facing humankind was brought about by economic development in industrial democracies.

\subsection{Democracy, Democratic Transitions and Economic Performance}

The positive effects of transitions to democracy on economic growth have been shown by Persson and Tabellini (2006) and Papaionnou and Siouronis (2008). In the Sub-Saharan African context, the most recent steady economic growth coincided with the decade-long international commodity boom that occurred during the first decade of the $21^{\text {st }}$ Century, large foreign debts cancellations and grants, and increased prevalence of democracy. Disentangling the causal factors influencing economic growth may not easily validate the economic development to democracy causality flow in Africa.

The influence of democratic elections on the macro-economy, sometimes called macro-economic aspects of political transitions, has been extensively analysed since the pioneering work of Nordhaus (1975). Nordhaus suggests that incumbent governments in a democratic setting tend to spend excessively during an election year in order to maintain political power. This excessive spending appears to be more common with emerging democracies (Alesina and Sachs, 1988; Acemoglu and Robinson, 2001, Gonsalez, 2002; Brender and Drazen, 2005; Rodrik and Wacziarg, 2005).

${ }^{3}$ For example, in 2018, the first female Chairperson of the Electoral Commission of Ghana was controversially dismissed by the President. This dismissal was criticised by large sections of the Ghanaian public, and questioned by several international agencies such as the United States Department of State (USDS) (refer to the USDS 2018 human rights report on Ghana, https://www.state.gov/documents/organization/289213.pdf, p. 13. 
Increased government expenditures are linked to the abuse of incumbency with emphasis on activities with short-term payoffs especially those programmes whose activities can be realised and visualised by voters during an election year.

Remmer (1993), using a time-series analysis of eight Latin American countries over the period, 1980 to 1991, showed that macroeconomic performance fluctuated with the electoral calendar. However, she argued that competitive elections had enhanced the willingness of political leaders in several countries to deal with outstanding macroeconomic management problems and issues including those arising from the transition from previously military dictatorships to civilian governments. Remmer's work involved the use of old time-series methodology that did not test for stationarity and unit roots of macro-economic variables.

Macroeconomic impacts of national elections in Ghana were analysed by Anaman (2016), using simple graphical analysis, showing adverse impacts of national presidential elections on macroeconomic indicators such as inflation and exchange rate. This analysis also indicated that macro-economic outcomes are worsened due to large deficits incurred by the incumbent governments in election years leading to inflation during the post-election years. The microeconomic analysis of impacts of democratic political transitions specifically on the performance of business firms in Ghana was undertaken by Anaman and Agyei-Sasu (2012). The effect of democratic political transition on the performance of business firms was mixed; return increased in an election year but declined in a transition year after an election. Government budget deficit in an election year had a negative impact on return.

In terms of democratic political transition, the Ghanaian political economy situation reveals an underlying problem that deals with the voting parity between the two main parties, which revolves around two ethnic-linked superstructures, made up of six relatively large social/ethnic groups, three each for the two main parties, whose vote wielding powers are largely based on mobilization of people on ethnic and regional differences during national presidential elections (Anaman, 2013; Bukari, 2017). The near-parity in the base voter wielding power of roughly $35 \%$ of voters for each of the two main political parties, in the more recent national elections, means that the incumbent government (political party) engages in excessive spending to attract swing voters (roughly 30 percent of the voting population) (Anaman, 2013; Bukari, 2017), often with promises which are difficult to fulfill once the party wins power.

The Ghanaian political economy situation is also different from emerging Southeast Asian democracies, such as Malaysia and Indonesia, which have achieved higher economic growth and more sustainable development than Ghana. Coalition-based politics, the norm in those countries, embrace citizens from different social/ethnic groups through inter-party winning coalitions (Anaman, 2006b), thus reducing the marginalisation of people from certain groups, who are sidelined from political appointments, once their political parties lose power, as is the case in Ghana, during the Fourth Republican era, which is essentially based on the "kokofu" political economy game system.

\section{Methodology}

\subsection{Introduction}

The aggregate impact of national presidential elections on the economy of Ghana during the Fourth Republican era was analysed based on the seven successive elections held in 1992, 1996, 2000, 2004, 2008, 2012 and 2016. The impact analysis was undertaken for four macroeconomic indicators, namely economic growth, government budget deficits, inflation and government treasury bond interest rates. Data on economic growth and government budget deficits are only available on an annual basis, and for only 25 years for the period of the study. However, for inflation rate and government 91-day Treasury bond rates, there are available monthly and quarterly data. For the 25 -year period from 1992 to 2016, there are 300 monthly data pieces and 100 quarterly data pieces.

\subsection{Measuring Impacts of Elections on Economic Growth and Budget Deficits}

Given the limited amount of annual data involving only 25 years, one approach for measuring the impact of elections on economic growth and budget deficits was to use graphical analysis to illustrate trends. The second approach was to use the Student $t$ test to ascertain the differences between the mean values of these two macroeconomic variables during the seven election years and the 18 non-election years during the period, 1992 to 2016.

The formula for the Student $t$ test is described in Equation 1

$$
t=\frac{\bar{x}_{1}-\bar{x}_{2}}{\sqrt{\left(s_{1}^{2}+s_{2}^{2}\right) /\left(n_{1}+n_{2-2}\right)}}
$$

where $\bar{x}_{1}$ denotes the average numerical value of the macroeconomic variable in the seven election years $(1992,1996$, 2000, 2004, 2008, 2012 and 2016), and $\overline{\boldsymbol{x}}_{2}$ denotes the average numerical value of the macroeconomic variable in the 18 non-election years. If the computed Student $t$ is greater than the critical $t$ value then we reject the null hypothesis that 
there was no statistically significant difference between the macroeconomic variable in the seven election years as compared to 18 non-election years and accept the alternative hypothesis that there was significant difference between the two periods.

\subsection{Measuring Impacts of Elections on Inflation and Interest Rates}

We used a simple autoregressive model to analyse the impact of elections on inflation and interest rates. It is generally accepted that simple models are preferred to complex models if these simple models produce results which are consistent with those observed in the real world. Given the relatively large amount of quarterly data available for inflation and interest rates, a time-series autoregressive model was constructed to analyse the impact of national elections on these two macro-economic variables during the period, 1992 to 2016. Following Remmer (1993), and applying modern econometrics including stationarity and unit root tests, the model used in this study for inflation is specified in Equation 2 below:

$$
\text { LINFLATION }_{\mathrm{t}}=\mathrm{B}_{0}+\begin{array}{r}
\mathrm{B}_{1} \text { LINFLATION }_{\mathrm{t}-1}+\mathrm{B}_{2} \text { LINFLATION }_{\mathrm{t}-2}+\ldots \ldots+\mathrm{B}_{\mathrm{p}} \text { LINFLATION }_{\mathrm{t}-\mathrm{p}}+\mathrm{C}_{1} \\
\text { PREELECQ }_{\mathrm{t}}+\mathrm{C}_{2} \text { ELECQ }_{\mathrm{t}}+\mathrm{C}_{3} \text { POSTELECQ }_{\mathrm{t}}+\mathrm{U}_{\mathrm{t}}
\end{array}
$$

where LINFLATION $_{\mathrm{t}}$ is the natural logarithm of INFLATION in quarter $\mathrm{t}$;

PREELECQ $Q_{t}$ is a dummy variable for the four quarters during a pre-election year (28 quarters altogether made up of seven pre-election years and four quarters), the pre-election year was the year just before the election year; a value of 1 was assigned for these 28 quarters. The value of zero was then assigned for all other quarters ( 72 altogether).

ELECQ $_{t}$ is a dummy variable for the four quarters during the an election year (28 quarters altogether made up of seven election years and four quarters); a value of 1 was assigned for these 28 quarters. The value of zero was then assigned for all other quarters (72 altogether).

POSTELECQ $\mathrm{t}$ is a dummy variable for the four quarters during the post-election year ( 28 quarters altogether made up of seven post-election years and four quarters), the post-election year was the year just after the election year; a value of 1 was assigned for these 28 quarters. The value of zero was then assigned for all other quarters ( 72 altogether). $U_{t}$ is the equation error term initially assumed to be normally distributed with zero mean and constant variance.

The second model deals with the quarterly treasury bond rate (TBR) and is indicated in Equation 3 as follows:

$$
\underset{\mathrm{LTBR}_{\mathrm{t}}}{=\mathrm{D}_{0}+\mathrm{D}_{1} \mathrm{LTBR}_{\mathrm{t}-1}} \underset{\underset{\text { POSTELECQ }}{\mathrm{t}}+\mathrm{V}_{\mathrm{t}}}{+\mathrm{D}_{2} \mathrm{LTBR}_{\mathrm{t}-2} \quad \ldots \ldots \ldots \ldots+} \mathrm{D}_{\mathrm{p}} \mathrm{LTBR}_{\mathrm{t}-\mathrm{p}}+\mathrm{E}_{1} \text { PREELECQ }_{\mathrm{t}}+\mathrm{E}_{2} \text { ELECQ }_{\mathrm{t}}+\mathrm{E}_{3}
$$

where LTBR is the natural logarithmic form of TBR; $V_{t}$ is the equation error term initially assumed to be normally distributed with zero mean and constant variance. The other variables are the same ones described earlier. Our analysis extends the work of Bukari (2017) by using a search for the optimal length of the lagged values based on the Schwarz Information Criterion, instead of the fixed lag length of two used by Bukari (2017).

\subsection{Data and Data Sources}

Data on annual economic growth, annual budget deficits from 1992 to 2016 were sourced from the various reports produced by the Ghana Statistical Service which are available from its website such as Ghana Statistical Service (2018a). Data on monthly and quarterly inflation were sourced from the Ghana Statistical Service. Data on government Treasury bill interest rates were obtained from the website of the Bank of Ghana.

\section{Results}

\subsection{Economic Growth}

The annual economic growth of Ghana from 1992 to 2016 is illustrated in Figure 2. Annual economic growth has been positive for each of the 25 years over the period with a low of 3.27 percent in 1994 and a high of 14.05 percent in 2011. The highest economic growth rate recorded in 2011 was due to the start of exports of commercially-produced oil from Ghana which impacted heavily on the industrial sector and the overall economy (Bukari, 2017). The positive economic growth over the 1992 to 2006 period also led to positive real per capita GDP as the economic growth outweighed the population growth rate. In Ghana, economic growth generally slows down due to economic shocks such as the El-Nino weather phenomenon (Anaman et al., 2017). Over this period, the El Nino phenomenon was partly responsible for reduced growth rates during 1999, 2007, 2014 and 2015.

Over the 25-year period from 1992 to 2016, there was positive economic growth measured by the growth of real GDP. Nevertheless, the growth of real GDP fluctuated throughout the period with peaks and troughs. For election years, there were no discernible patterns in the growth of real GDP. Discerning the specific impact of elections on economic growth, it was established that the average economic growth over the entire 25-year period from 1992 to 2016 was 5.51 percent. For the seven election years, the average annual economic growth was 5.67 percent while the annual economic growth 
rate for the 18 non-election years was 5.45 percent. Hence there was 0.22 percent difference between the average for the election years and the average for the non-election years. The computed Student $t$ value for the test of the difference in the average economic growth figures for the two time periods (seven election years and 18 non-election years) was 0.295 compared to the critical $t$ value for 23 degrees of freedom of 2.069. Hence, it is concluded that the average growth rate of election years was not statistically different from the average recorded for non-election years.

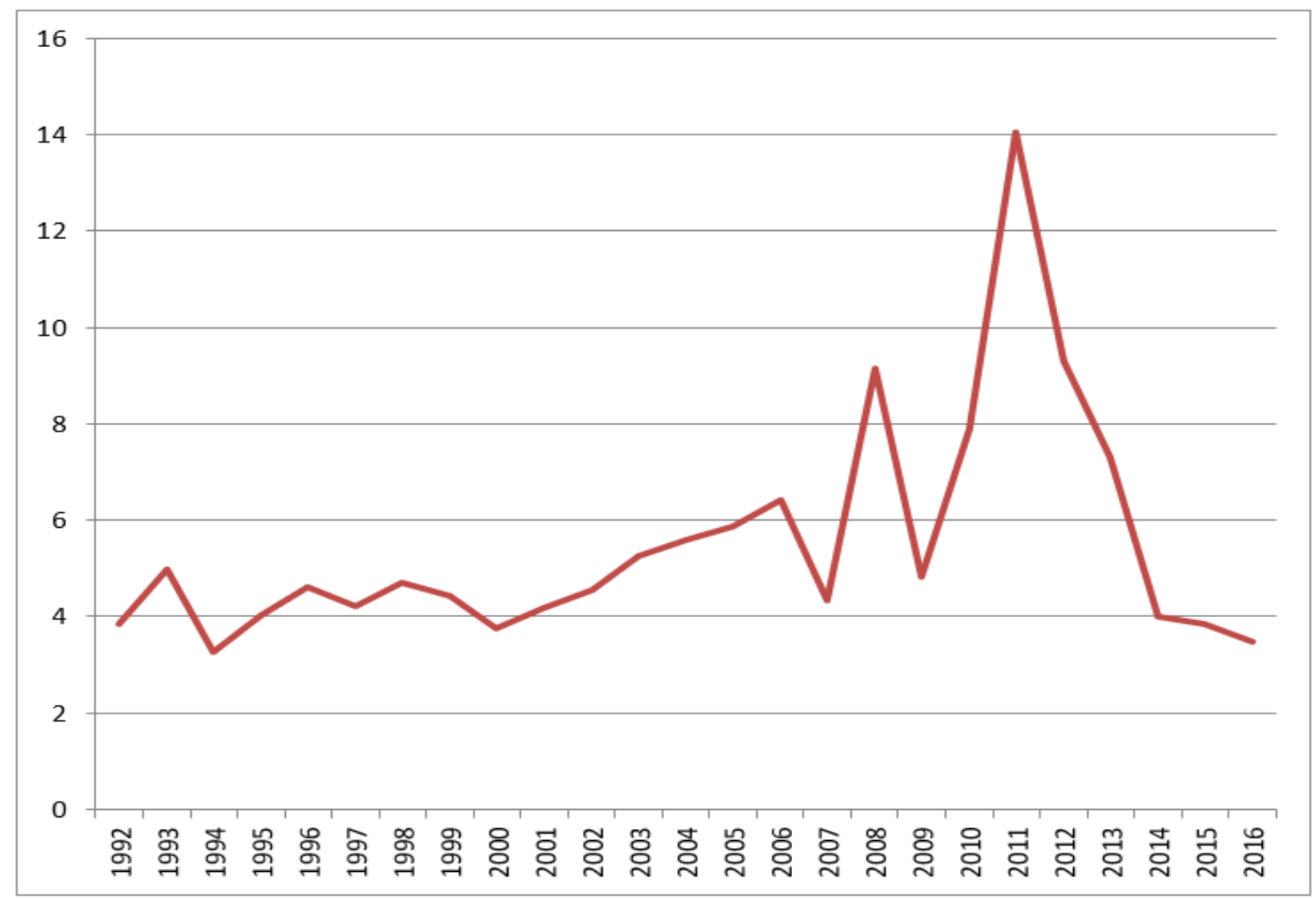

Figure 2. Illustration of Annual Economic Growth Rates in Ghana from 1992 to 2016

Source: The figure was developed based on data obtained from the Ghana Statistical Service (2018a)

\subsection{Government Budget Deficits}

Government budget deficits are the amounts of money that the government spends beyond the level of the total revenues and grants that the government collects. Government budget deficits essentially add to the total debts stock of the country and lead to crowding out the private sector as government consistently borrows from the money and capital markets to finance its expenditures. Budget deficit to GDP ratios tended to be very high during years of national presidential elections (Bukari, 2017). The highest deficit ratios recorded in the Fourth Republican period were 11.8 percent and 11.5 percent in 2012 and 2008 respectively; both years were election years. As shown in Figure 3 indicates that government budget deficits are generally very high during election years.

Ascertaining the specific impact of elections on government budget deficit to GDP ratios, it is noted that there were seven election years and 18 non-election years over the 1992 to 2016 period. The average budget deficit to GDP ratio over the entire 25-year period from 1992 to 2016 was 5.89 percent of GDP. For the seven election years, the average annual budget deficit to GDP ratio was 8.03 percent of GDP. The average annual budget deficit to GDP ratio in the 18 non-election years was 5.06 percent of GDP. Hence there was 2.967 percent of GDP difference between the average deficit to GDP ratio for the two time periods. The computed Student $t$ value for the difference in the mean values of the budget deficit to GDP ratio between the two time periods was 3.484; this figure was much higher than the critical Student $t$ value for 23 degrees of freedom of 2.069. Hence, given the limited sample size of 25 years, one can conclude cautiously that election years produced statistically higher budget deficit to GDP ratios than during non-election years in the Fourth Republican era in Ghana. 


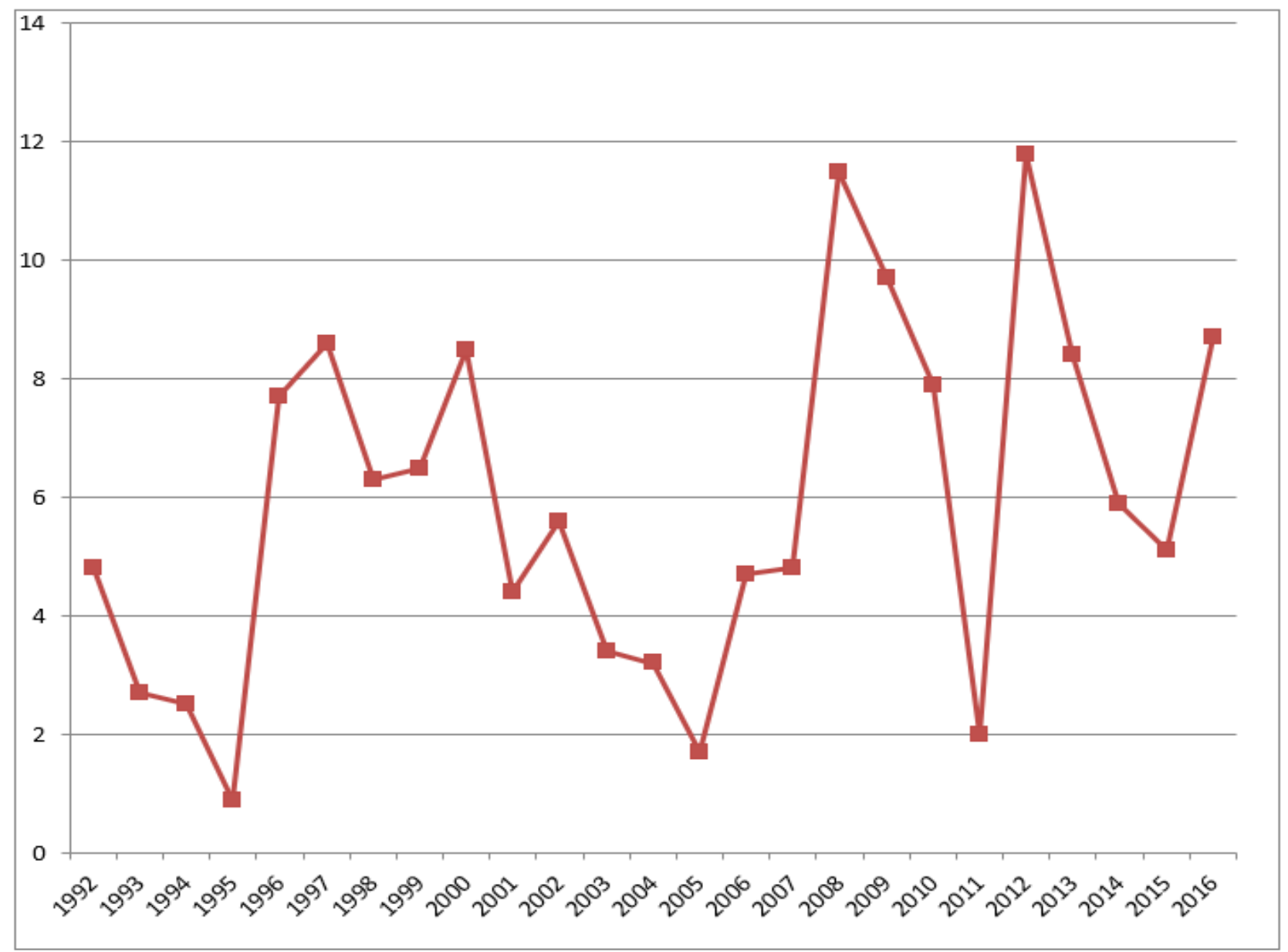

Figure 3. Illustration of Government Budget Deficit to GDP Ratios from 1992 to 2016

Source: The figure was developed based on data compiled from Ghana Statistical Service (GSS) (2018a), and data from GSS website, and also data from Bukari (2017).

\subsection{Unit Root Tests for Inflation and Interest Rates Variables}

The ordinary least squares (OLS) estimation method was used to estimate the autoregressive equations involving both inflation and government treasury bill rates. The use of the OLS method for such time-series estimation required that the variables were stationary. The test of stationarity was therefore conducted for both LINFLATION and LTBR based on the analysis of unit roots. The unit root tests were conducted with the Augmented Dickey-Fuller (ADF) test (Dickey and Fuller, 1979; Dickey and Fuller, 1981) and the Phillip Perron (PP) test (Phillips and Perron, 1988). The null hypothesis for both tests was that there was a unit root in the time series. The PP test of stationarity is generally preferred to the ADF test partly because the former test is more efficient in distinguishing between non-stationary and stationary time-series with high degree of autocorrelation (Hall and Cummins, 2009).

The unit root test results are reported in Table 1, using the ADF and PP tests, and for the two variables, LINFLATION and LTBR. The results showed that the two variables were non-stationary at their levels but were stationary based on their first differences. The only exception was for the PP test value for LINFLATION which was both stationary at the level and at the first difference (refer to Table 1). Hence the autoregressive model analysis outlined in Equations 2 and 3 , was undertaken based on the first differences of the variables denoted as DLINFLATION and DLTBR, respectively. The lag length of the autoregressive analysis was determined to be four (quarters) for both the DLINFLATION and DLTBR models, based on the minimum values of the Schwarz Information Criterion, and the absence of significant econometric problems using various diagnostic tests. The optimal lag length of four quarters was also equivalent to one calendar year (lagged year). 
Table 1. Unit Root Tests of the Variables at the Levels and First Differences

\begin{tabular}{lllll}
\hline Variable & ADF Statistic & P Value & PP Statistic & P Value \\
\hline LINFLATION & -4.672 & $0.0008^{* *}$ & -16.703 & 0.135 \\
LTBR & -2.716 & 0.230 & -12.064 & 0.313 \\
DLINFLATION & -4.443 & $0.002^{* *}$ & -60.204 & $0.00001^{* *}$ \\
DLTBR & -5.123 & $0.0001^{* *}$ & -60.375 & $0.00001^{* *}$ \\
\hline
\end{tabular}

Notes

DLINFLATION and DLTBR are the first differences of the variables, LINFLATION and LTBR respectively.

LINFLATION and LTBR are the natural logarithmic forms of the linear variables, INFLATION and TBR respectively.

** denotes 5 percent statistical significance.

\subsection{Time-Series Analytic Results for Inflation}

The results of the autoregressive model analysis for inflation (INFLATION) are reported in Table 2. The dependent variable is DLINFLATION, which is the first difference of LINFLATION. DLINFLATION is equivalent to the quarterly growth of the inflation rate because the first difference of a natural logged variable represents the growth rate of the level variable (refer to Gujarati, 2003, p. 176). The lagged dependent variables, used for the independent variables, were proxied by their instrumental variables, based on the first differences of these variables, similar to the approach used by Heintz and Ndikumana (2009, p. ii79). The results using this approach provided a credible significant model based on both the $\mathrm{R}^{2}$ and the $\mathrm{F}$ value and the correct specification of the model from the relevant diagnostic test (Ramsey Reset test; Ramsey, 1969) compared to the low level of significance, the presence of econometric problems such as non-normality of the equation error term and heteroscedasticity from the model results using just the lagged dependent variables.

The power of the chosen model (Table 2) was modestly strong based on the relatively high $\mathrm{R}^{2}$ of $68.6 \%$ and an adjusted $\mathrm{R}^{2}$ of $66.0 \%$. The model was correctly specified based on the Ramsey Reset test of specification (Ramsey, 1969) with the $\mathrm{p}$ value for the null hypothesis of correct model specification being $80.2 \%$ which was much higher than the statistical significance level adopted in this study (5\%). Given the relatively modest sample size of 100 used for the analysis, the test for the normality of the error term was important. The Shapiro-Wilk test for normality of the equation error term clearly confirmed the normality of the error term with a p value of 0.145 (refer to Table 2). A similar result was obtained using the Jarque-Bera test (Jarque and Bera, 1987). Hence it could be argued that the sample results related to the parameter estimates could be generalised to the general population.

There was no significant heteroscedasticity in the model based on the Gleijser (1969) test (refer to Table 2). A similar result was obtained for heteroscedasticity using the Langrange Multiplier (LM) test proposed by Hall and Cummins (2009). Based on the maximum condition index of 30.203, it was concluded that there was no severe multicollinearity problem in the model as this value was just around value of 30.0, beyond which severe multicollinearity could be present, based on recommendations of Gujarati (2003, p. 362). Further, using the Breusch-Godfrey general test for autocorrelation (Breusch, 1978; Godfrey, 1978; Gujarati, 2003, pp. 473-474), the model was assessed to have no significant autocorrelation.

The results of the analysis reported in Table 2 confirmed that all the parameters of the independent variables of the model, with the exception of the post-election year dummy variable (POSTELECQ P $_{t}$, were statistically significant at the $5 \%$ level used for this study. Specifically for election-related variables, the pre-election year and election year variables had their parameters statistically significant. The results suggested that inflation increased during both election years and pre-election years when compared to all other years. Based on the standardized regression estimates, which measured the relative ranking of the influence of the independent variables on the dependent variable, it could be ascertained from Table 2 that the election year was the most dominant of the three election year variables.

Finally, the parameters of all four lagged dependent variables were also statistically significant with the first and third year lagged dependent variables having positive impact on the dependent variable. However, the second and fourth order variables had negative impact on the dependent variable. Using the standardized regression estimates, the most important lagged dependent variable was the one based on the third order, which also was the most important of all the seven independent variables. 
Table 2. Results of simple autoregressive analysis between the growth of quarterly inflation rate in Ghana and national election variables (PREELECQ, ELECQ, POSELECQ) during the Fourth Republican era from 1992 to 2016.

Dependent Variable is DLINFLATION ${ }_{\mathrm{t}}$

\begin{tabular}{lllll}
\hline Explanatory Variable & $\begin{array}{l}\text { Parameter } \\
\text { Estimate }\end{array}$ & $\begin{array}{l}\text { Standardised } \\
\text { Parameter } \\
\text { Estimate }\end{array}$ & T-statistic & P Value \\
\hline INTERCEPT & -0.041 & 0.000 & -1.910 & 0.059 \\
DLINFLATION $_{\mathrm{t}-1}$ & 1.894 & 2.233 & 11.907 & $0.000^{* *}$ \\
DLINFLATION $_{\mathrm{t}-2}$ & -2.312 & -4.608 & -8.241 & $0.000^{* *}$ \\
DLINFLATION $_{\mathrm{t}-3}$ & 1.366 & 4.966 & 6.485 & $0.000^{* *}$ \\
DLINFLATION $_{\mathrm{t}-4}$ & -0.316 & -2.141 & -5.378 & $0.000^{* *}$ \\
PREELECQ $_{\mathrm{t}}$ & 0.062 & 0.152 & 1.994 & $0.049^{* *}$ \\
ELECQ $_{\mathrm{t}}$ & 0.065 & 0.159 & 2.137 & $0.035^{* *}$ \\
POSTELECQ $_{\mathrm{t}}$ & 0.052 & 0.125 & 1.620 & 0.107 \\
\hline
\end{tabular}

Notes

Sample size 100

$\mathrm{R}^{2}$ $0.686^{* *}$

Adjusted $\mathrm{R}^{2} \quad 0.660^{* * *}$

F value $\quad 27.111 * *$

Probability level of significance of correct specification of the model using

Ramsey Reset test with the null hypothesis of correct specification

Probability level of significance of the normality of the error term of the model using Shapiro-Wilk test with the null hypothesis of normal error term

Probability level of significance of heteroscedasticity in the model using Gleijser test with null hypothesis of no heteroscedasticity

* denotes 5 percent statistical significance.

\subsection{Time-Series Analytic Results for Interest Rates}

The results of the autoregressive model analysis for government Treasury bond rate (TBR) are reported in Table 3 . The dependent variable is DLTBR, which is the first difference of LTBR. Hence DLTBR is the quarterly growth rate of TBR. The power of the model was high with $\mathrm{R}^{2}$ of $74.2 \%$ and adjusted of $\mathrm{R}^{2}$ of $72.2 \%$. Further, the model was correctly specified based on the Ramsey Reset result with the computed $\mathrm{p}$ value of 0.186 above the critical value of 0.05 used for this study. The equation error term was also assessed to be normally distributed based on the Shapiro-Wilk test. The test of heteroscedasticity based on the Gleijser test revealed no significant problem. Based on the maximum condition index of 27.978 , it was concluded that there was no significant multicollinearity problem in the model as this value was below the value of 30.0 that would trigger suspicion of severe multicollinearity based on recommendations of Gujarati (2003, p. 362).

The results shown in Table 3 showed that all the parameters of the independent variables of the model, with the exception of the pre-election year dummy variable (PREELECQ $\left.\mathrm{t}_{\mathrm{t}}\right)$ were statistically significant at the $5 \%$ level used for this study. Specifically for election-related variables, the post-election year and election year variables had their parameters statistically significant. The results suggested that interest rates increased during both election years and post-election years when compared to all other years. Based on the standardized regression estimates, the results shown in Table 3 indicated that the post-election year was the most dominant of the three election year variables.

As shown in Table 3, the parameters of all four lagged dependent variables were also statistically significant with the first and third year lagged dependent variables having positive impact on the dependent variable. However, the second and fourth order variables had negative impact on the dependent variable. Based on the standardized regression estimates, the most important lagged dependent variable was the second order, which was also the most important of all the seven independent variables. 
Table 3. Results of simple autoregressive analysis between the growth of quarterly treasury bill rate in Ghana and national election variables (PREELECQ, ELECQ, POSELECQ) during the Fourth Republican era from 1992 to 2016.

Dependent Variable is DLTBR $\mathrm{t}_{\mathrm{t}}$

\begin{tabular}{lllll}
\hline Explanatory Variable & Parameter Estimate & $\begin{array}{l}\text { Standardised } \\
\text { Parameter Estimate }\end{array}$ & T-statistic & P Value \\
\hline INTERCEPT & -0.056 & 0.000 & -3.570 & $0.001^{* *}$ \\
DLTBR $_{\mathrm{t}-1}$ & 2.046 & 2.292 & 12.772 & $0.000^{* *}$ \\
DLTBR $_{\mathrm{t}-2}$ & -2.374 & -4.112 & -8.555 & $0.000^{* *}$ \\
DLTBR $_{\mathrm{t}-3}$ & 1.255 & 4.081 & 6.465 & $0.000^{* *}$ \\
DLTBR $_{\mathrm{t}-4}$ & -0.269 & -1.638 & -4.977 & $0.000^{* *}$ \\
PREELECQ $_{\mathrm{t}}$ & 0.038 & 0.117 & 1.724 & 0.088 \\
ELECQ $_{\mathrm{t}}$ & 0.091 & 0.276 & 4.051 & $0.000^{* *}$ \\
POSTELECQ $_{\mathrm{t}}$ & 0.093 & 0.279 & 3.984 & $0.000^{* *}$
\end{tabular}

\section{Notes}

Sample size $\quad 100$

$\mathrm{R}^{2} \quad 0.742 * *$

Adjusted $\mathrm{R}^{2} \quad 0.722 * *$

F value $\quad 35.824 * *$

Probability level of significance of correct specification of the model using

Ramsey Reset test with null hypothesis of adequately correct specification

Probability level of significance of the normality of the error term of the model

using the Shapiro-Wilk test with null hypothesis of normal error term

Probability level of significance of heteroscedasticity in the model

using the Gleijser with null hypothesis of no heteroscedasticity

* denotes 5 percent statistical significance.

\section{Conclusions and Recommendations}

\subsection{Conclusions}

We analysed the macroeconomic impact of national presidential elections in Ghana over the Fourth Republican period from 1992 to 2016 partly using simple autoregressive models. The statistical analysis undertaken involved economic growth, government budget deficits, inflation, and Treasury bond interest rates. Based on annual data from 1992 to 2016, we found out that elections did not lead to significant increase in economic growth. However, the increase in government budget deficits during election years was established. Using quarterly data covering 100 periods from 1992 to 2016, we showed that election years produced statistically significant higher levels of inflation and interest rates. Overall, national elections in Ghana in the Fourth Republican era do not enhance economic growth despite the large increases in budget deficits that they create that lead to increased inflation and interest rates. There is evidence of continuing negative impact of elections in Ghana as shown by the pre-election year large depreciation of the Ghanaian currency, the Ghana cedi. During the first three months of 2019, a pre-election year, the local currency depreciated by about $11 \%$ making it among the worst performing currencies in the world for this period. This situation is similar to what was observed in 2011/2012 and 2014/2015, which were also pre-election years.

\subsection{Recommendations}

From a political economy perspective, given the essentially antagonistic two-party ethnicity-based competitive political party system in Ghana, a solution to the excessive government spending during election years lies in the reduction of the intense nature of fighting for political power. From a game-theoretic perspective, this would involve changing the two-party zero-sum non-cooperative game into a non-zero-sum cooperative game. This can be done by reducing the level of intensity of the winner-takes-all political system which is built around the constant mobilization for political power through appealing to ethnic and regional differences by politicians from the two main political parties. Therefore we suggest that continuous efforts need to be made to have District Chief Executives (DCEs) and Mayors of the 260 districts to be directly elected by local citizens who will hold them accountable for problems in their local areas that are 
directly within the realm of DCEs and Mayors as noted by Anaman (2006a).

This direct election of DCEs and Mayors is likely to reduce the intensity of political power struggle of the two main parties, and allow for the emergence of viable third parties, and also allow citizens from marginalized groups to participate more deeply in governance, as voters elect candidates based on their perceived ability to deliver goods and services at the local level. This is likely to lead to improved local governance and solution to severe local problems such as the very poor environmental sanitation characterized by widespread open urination and open defecation in public spaces, and inadequate provision of basic solid and liquid waste collection services, water and health services in many areas of the country.

The deeper level of decentralization envisaged from direct election of DCEs and Mayors could also accelerate the growth of internally-generated funds to reduce the dependence of district assemblies or councils on the Central Government which is severely constrained of funds as discussed earlier. During the First Republic (1960-1966), a notable feature was the development of 700 local councils which were largely self-financing with most of these local councils constructing their headquarters and offices using internally-generated funds often anchored around well-developed village and town market centres, effective collection of local taxes such as poll tax and property rates, and the regular mobilisation of community labour for development activities. The extensive decentralization with about 700 local councils also allowed for greater participation in local governance by citizens from small and marginalised social/ethnic groups in the country. The reduction of local councils to 65 district councils in 1971 destroyed their self-financing status and increased their dependence on the Central Government for development funds, and worsened the socio-economic conditions of people from many relatively small social/ethnic groups.

Appendix: Levels of Grants Received by the Government of Ghana in both Ghana Cedis and the United States dollar and the Population of Ghana from 2000 to 2017.

\begin{tabular}{|c|c|c|c|c|}
\hline Year & $\begin{array}{l}\text { Grants in } \\
\text { Ghana Cedis }\end{array}$ & $\begin{array}{l}\text { Exchange Rate Ghana } \\
\text { Cedi per one United } \\
\text { States dollar }\end{array}$ & $\begin{array}{l}\text { Grants in United States } \\
\text { dollars }\end{array}$ & Population \\
\hline 2000 & $57,430,500$ & 0.545 & $105,377,060$ & $18,912,079$ \\
\hline 2001 & $156,995,800$ & 0.716 & $219,267,880$ & $19,420,581$ \\
\hline 2002 & $152,458,300$ & 0.792 & $192,497,850$ & 0948080 \\
\hline 2003 & $\begin{array}{l}311,877,010 \\
483,065,010\end{array}$ & 0.867 & $359,719,740$ & $\begin{array}{l}20,4 / 0,909 \\
21.029,628\end{array}$ \\
\hline 2004 & & 0.899 & $537,335,940$ & 21505073 \\
\hline 2005 & $510,016,260$ & 0.906 & $562,931,860$ & 22175721 \\
\hline 2006 & $634,856,000$ & 0.916 & $693,074,240$ & 22771982 \\
\hline 2007 & $857,223.69$ & 0.935 & $916,816,780$ & $23,384.275$ \\
\hline 2008 & $817,290,700$ & 1.058 & $772,486,480$ & 24013031 \\
\hline 2009 & $1,101,184,390$ & 1.409 & $781,536,120$ & 24658823 \\
\hline 2010 & $1,080,232,890$ & 1.431 & $754,879,730$ & $24,030,020$ \\
\hline 2011 & $1,174,959,240$ & 1.512 & $777,089,440$ & 26002567 \\
\hline 2012 & $1,160,321,340$ & 1.810 & $641,061,520$ & 26701724 \\
\hline $\begin{array}{l}2013 \\
2014\end{array}$ & $\begin{array}{l}739,441,870 \\
814,136,610\end{array}$ & $\begin{array}{l}1.920 \\
2.940\end{array}$ & $\begin{array}{l}385,125,970 \\
276,917,210\end{array}$ & $27,419,680$ \\
\hline 2015 & $2,688,756,370$ & 3.780 & $711,311,210$ & $28,156,940$ \\
\hline 2016 & $1,140,726,850$ & 3.920 & $291,001,750$ & $4,0<4$ \\
\hline 2017 & $1,534,852,220$ & 4.360 & $352,030,320$ & $29,091,404$ \\
\hline
\end{tabular}

Notes

The grant figures are obtained from the Bank of Ghana (Central Bank of Ghana). The population projections are estimated from actual figures for Ghana for 1984, 2000 and 2010 as published by the Ghana Statistical Service (2013). 


\section{References}

Acemoglu, D., \& Robinson, J. A. (2001). A theory of political transitions. The American Economic Review, 91(4), 938-963. https://doi.org/10.1257/aer.91.4.938

Alesina, A., \& Sachs, J. (1988). Political parties and the business cycle in the United States, 1948-1984. Journal of Money, Credit and Banking, 20(1), 63-68. https://doi.org/10.2307/1992667

Anaman, K.A. (2006a). Determinants of Economic Growth in Ghana. Accra: Institute of Economic Affairs.

Anaman, K. A. (2006b). Economic and Social Policies Adopted by Dynamic Southeast Asian Countries: How Applicable are they to Ghana and Africa? Accra: Institute of Economic Affairs.

Anaman, K. A. (2013). Structuralism political economy theory related to ethnicity factor in elections in Ghana: statistical estimation of proportions of Asantes and Ewes who voted for NPP and NDC respectively in the 2012 national presidential election with examples from selected districts in the Ashanti and Volta regions. Political Economy and Development Class Notes, Accra, Ghana: University of Ghana.

Anaman, K. A. (2016). Impact of democratic political transition on the economy of Ghana, in Ninsin, Kwame A. (ed.), Issues in Ghana's Electoral Politics, Dakar, Senegal: Council for the Development of Social Science Research in Africa, 135-152 (April).

Anaman, K. A., \& Agyei-Sasu, F. (2012). Impact of democratic politic al transition on the performance of business firms in Ghana. Economic Papers: A Journal of Applied Economics and Policy, 31(3), 391-400. https://doi.org/10.1111/j.1759-3441.2011.00151.x

Anaman, K. A., \& Agyei-Sasu, F. (2014). The economic value of the environmental capital inputs used to produce gross domestic product in Ghana, 1993 to 2012. Research in World Economy, 5(2), 74-92. https://doi.org/10.5430/rwe.v5n2p74

Anaman, K. A., Quaye, R., \& Amankwah, E. (2017). Evaluation of the public weather services by users in the formal services sector in Accra, Ghana. Modern Economy, 8, 921-945. https://doi.org/10.4236/me.2017.87065

Bank of Ghana. (2018). Statistics and Publications. Available from https://www.bog.gov.gh/whars-new, accessed on 14 December 2018.

Boakye, S. (2017). Fiscal Rigidities and Their Effects in Ghana: What Should the Government Do? Occasional Paper Number 9, Accra, Ghana: Institute for Fiscal Studies.

Boakye, S. (2018). "Ghana beyond aid" remains a mere national aspiration. Paper Presented at a Dinner Conversation at La Villa Boutique Hotel, Osu, Accra, Ghana on the Theme "Ghana Beyond Aid", 4 November.

Brender, A., \& Drazen, A. (2005). Political budget cycles in new versus established democracies. Journal of Monetary Economics, 52(7), 1271-1295. https://doi.org/10.1016/j.jmoneco.2005.04.004

Breusch, T. S. (1978). Testing for autocorrelation in dynamic linear models. Australian Economic Papers, 17, 334-335. https://doi.org/10.1111/j.1467-8454.1978.tb00635.x

Buah, F. K. (1998). A History of Ghana. London: MacMillan Education Limited.

Bukari, G. A. (2017). Political Economy Analysis of Elections in Ghana's Fourth Republic (1992 to 2016). Doctor of Philosophy Thesis, Accra, Ghana: University of Ghana.

Davidson, B. (1972). History of Africa. London: Spring Books.

Dewan, T., \& Shepsle, K. A. (2011). Political economy models of elections. Annual Review of Political Science, 14, 311-330.

Dickey, D., \& Fuller, W. A. (1979). Distribution of the estimates for autoregressive time series with a unit root. Journal of the American Statistical Association, 74, 427-431.

Dickey, D., \& Fuller, W. A. (1981). Likelihood ratio statistics for autoregressive time series with a unit Root. Econometrica, 49, 1057-1072. https://doi.org/10.2307/1912517

Downs, A. (1957). An Economic Theory of Democracy. New York: Harper and Row.

Fernandez, A., Schmitt-Grohe, S., \& Uribe, M. (2017). World shocks, world prices, and business cycles: an empirical investigation. Journal of International Economics, 108, S2-S14. https://doi.org/10.1016/j.jinteco.2017.01.001

Ghana Statistical Service (GSS). (2013). 2010 National Population and Housing Census: National Analytic Report. Accra: GSS.

Ghana Statistical Service (GSS). (2014). Ghana Living Standards Survey (GLSS) Round 6 Main Report. Accra: GSS. 
Ghana Statistical Service (GSS). (2018a). Provisional 2017 Annual Gross Domestic Product April 2018 Edition. Accra: GSS.

Ghana Statistical Service (GSS). (2018b). Ghana Living Standards Survey (GLSS)Round 7 Report. Accra: GSS.

Glejser, H. (1969). A new test for heteroscedasticity. Journal of the American Statistical Association, 64, 316-323. https://doi.org/10.1080/01621459.1969.10500976

Godfrey, L. G. (1978). Testing against general autoregressive and moving average error models when the regressors include lagged dependent variables. Econometrica, 46, 1293-1302. https://doi.org/10.2307/1913829

Gonsalez, M. D. L. A. (2002). Do changes in democracy affect the political budget cycle? evidence from Mexico. Review of Development Economics, 6(2), 204-224. https://doi.org/10.1111/1467-9361.00150

Government of Ghana (2018). Mid-Year Fiscal Policy Review of the 2018 Budget Statement and Economic Policy Presented to Parliament on 19 July 2018 by the Minister of Finance. Accra: Ministry of Finance.

Gujarati, B. N. (2003). Basic Econometrics, Fourth Edition. New York: Prentice-Hall.

Hall, B. H., \& Cummins, C. (2009). Time Series Processor (TSP) Version 5 Reference Manual. Palo Alto, California: TSP International.

Harding, R., \& Wantchekon, L. (2010). The Political Economy of Human Development. New York: United Nations Development Programme.

Heintz, J., \& Ndikumana, L. (2009). Is there a case for formal inflation targeting in Sub-Saharan Africa. Journal of African Economies, 20(2), ii67-ii103.

Hersh, S. M. (1978). C. I. A. said to have aided plotters who overthrew Nkrumah in Ghana. New York Times, 9 May, https://www.nytimes.com/1978/05/09/archives/cia-said-to-have-aided-plotters-who-overthrew-nkrumah-in-ghana.h tml, New York: New York Times, accessed 8 January 2019.

Hicks, J. (1939). The foundations of welfare economics. Economic Journal, 49(196), 696-712. https://doi.org/10.2307/2225023

Institute of Fiscal Studies (IFS) (2018). Mid-Year Review of the 2018 Budget Statement and Economic Policy of the Government of Ghana: Comments from the IFS, Accra: IFS.

International Cocoa Organisation (ICCO). Quarterly Bulletin of Cocoa Statistics, Various Issues. Abidjan, Ivory Coast: ICCO.

Jarque, C. M., \& Bera, A. K. (1987). A test for normality of observations and regression residuals. International Statistical Review, 55, 163-172. https://doi.org/10.2307/1403192

Kaldor, N. (1939). Welfare propositions and interpersonal comparisons of utility. Economic Journal, 49(195), 549-552. https://doi.org/10.2307/2224835

Lipset, S. M. (1959). Some social requisites of democracy: economic development and political legitimacy. The American Political Science Review, 53(1), 69-105. https://doi.org/10.2307/1951731

Lipset, S. M. (1960). Political Man: The Social Bases of Politics. Garden City: Doubleday.

Nash, J. F. (1950). Equilibrium points in n-person games. Proceedings of the National Academy of Sciences, 36(1), 48-49. https://doi.org/10.1073/pnas.36.1.48

Nash, J. F. (1951). Non-cooperative games. Annals of Mathematics, 54(2), 286-295. https://doi.org/10.2307/1969529

Nordhaus, W. (1975). The political business cycle. Review of Economic Studies, 42, 169-90. https://doi.org/10.2307/2296528

Olson, M. (1993). Dictatorship, democracy, and development. The American Political Science Review, 87(3), 567-576. https://doi.org/10.2307/2938736

Papaioannou, E., \& Siourounis, G. (2008). Economic and social factors driving the third wave of democratization. Journal of Comparative Economics, 36(3), 365-387. https://doi.org/10.1016/j.jce.2008.04.005

Pareto, W. (1906). Manual of Political Economy. Oxford: Oxford University Press.

Persson, T., \& Tabellini (2006). Democracy and development: the devil in the details. The American Economic Review, 319-324. https://doi.org/10.1257/000282806777212396

Phillips, P., \& Perron, P. (1988). Testing for a unit root in time-series regression. Biometrica, 75, 335-346. https://doi.org/10.1093/biomet/75.2.335 
Przeworski, A. (2005). Democracy as an equilibrium. Public Choice, 123(3), 253-273. https://doi.org/10.1007/s11127-005-7163-4

Ramsey, J. S. (1969). Tests for specification errors in classical linear least squares regression. Journal of the Royal Statistical Society, Series B, 350-371. https://doi.org/10.1111/j.2517-6161.1969.tb00796.x

Remmer, K. L. (1993). The political economy of elections in Latin America, 1980-1991. American Political Science Review, 87(2), 393-407. https://doi.org/10.2307/2939049

Rodrik, D., \& Wacziarg, R. (2005). Do democratic transitions produce bad economic outcomes? American Economic Review, 95(2), 50-55.

Rogoff, K., \& Sibert, A. (1988). Elections and macroeconomic policy cycles. Review of Economic Studies, 55, 1-16. https://doi.org/10.2307/2297526

Sackrey, C., Schneider, G., \& Knoedler, J. (2016). Introduction to Political Economy Eighth Edition, Boston: Dollars and Sense, Economic Affairs Bureau.

Shapiro, S. S., \& Wilk, M. B. (1965). An analysis of variance test for normality (complete samples). Biometrika, 52(3-4), 591-611. https://doi.org/10.1093/biomet/52.3-4.591

Sweezy, P. M. (1939). Demand under conditions of oligopoly. The Journal of Political Economy, 47, 568-573.

United States Department of State (USDS) (2019). Ghana 2018 Human Rights Report. Washington, D.C: USDS, https://www.state.gov/documents/organization/289213.pdf, accessed 21 March 2019.

Von Neumann, J., \& Morgenstern, O. (1944). Theory of Games and Economic Behaviour. Princeton: Princeton University Press.

Weingast, B. R., \& Wittman, D. A. (2006). The Oxford Handbook of Political Economy. Oxford: Oxford University Press.

World Health Organization (WHO, 2018). World Health Rankings: Road Traffic Accidents, https://www.worldlifeexpectancy.com/cause-of-death/road-traffic-accidents/by-country, accessed 16 March 2019.

World Health Organization \& United Nations International Children's Emergency Fund (WHO \& UNICEF, 2017). Progress on Drinking Water, Sanitation and Hygiene 2017: Update and SDG Baselines. Geneva: Joint WHO/UNICEF Monitoring Group.

Yale University (2018). 2018 Environmental Performance Index. New Haven: Yale University, http://www.epi.yale.edu, accessed on 15 January 2019.

\section{Copyrights}

Copyright for this article is retained by the author(s), with first publication rights granted to the journal.

This is an open-access article distributed under the terms and conditions of the Creative Commons Attribution license which permits unrestricted use, distribution, and reproduction in any medium, provided the original work is properly cited 